International Journal of Pediatric Research and Reviews

(ISSN:2637-4978)

\title{
PEDIATRICAL STORY CONTAINING: THE CONTRIBUTION OF EXTENSION PROJECT FOR TRAINING OF MEDICINE STUDENTS
}

\author{
Alayde Parisina Dutra Cabral de Carvalho ${ }^{1 *}$, Bianca Dantas dos Santos Ramos ${ }^{2}$, Maria \\ Cecília Barbosa de Oliveira $^{3}$, Eliane Nóbrega ${ }^{4}$, Mônica Osório ${ }^{5}$
}

${ }^{1,2,3}$ Estudantes FPS ${ }^{4,5}$ Tutor FPS

\section{ABSTRACT}

Background: Child hospitalization has a direct impact on the life of children who move away from a school, leisure and social routine, experiencing biopsychosocial repercussions. University extension projects in the hospital context can contribute to humanization and mental health prevention actions, as well as to develop professional skills of undergraduate health extension students. Objective: To develop reflections on the contribution of the Storytelling Project in pediatrics in a Recife hospital to train medical students. Methodology: Experience report. Results and discussion: In the project in question, medical students interact with students from pharmacy, psychology, nursing from the training activity and in the experience exchange meetings. In the child's approach to storytelling in the ward and pediatric emergency room, they experienced welcoming each other, dedicating their time to the patient, making choices when selecting books and narrating them, the ability to communicate and interact. inserting the child in the plot read. This was an activity that required calmness, availability for the other, adjusting their time to the rhythm, physical conditions and illness of the patient. Thinking of a professional future as doctors, it was reflected that it will be necessary to welcome and tell "stories" to patients, whether as surgeries happened, or as a treatment, or what is a disease. This experience posed the students facing the challenge of dealing with the other's cognitive and emotional reaction, dealing with resistance to participate, facing competition from the technological world, which makes it difficult to perform calmly in the hospital, as people are always in a hurry and involved in our world of chores and social networking. Final Considerations: Thus, it is believed that in the future, this project will impact the formation of students from various areas of higher health courses, highlight-

*Correspondence to Author:

Alayde Parisina Dutra Cabral de Carvalho

\section{FPS}

How to cite this article:

Alayde Parisina Dutra Cabral de Carvalho, Bianca Dantas dos Santos Ramos, Maria Cecília Barbosa de Oliveira, Eliane Nóbrega, Mônica Osório. PEDIATRICAL STORY CONTAINING: THE CONTRIBUTION OF EXTENSION PROJECT FOR TRAINING OF MEDICINE STUDENTS. nternational Journal of Pediatric Research and Reviews, $2020,3: 20$

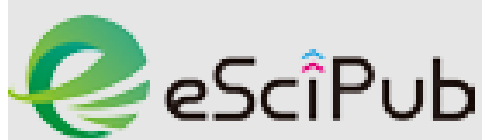

eSciPub LLC, Houston, TX USA. Website: https://escipub.com/ ing the need to devote attention, welcome and fully care for the patient.

Keywords: Extension project, pediatrics, medicine, training. 